\title{
The Effect of Aromatherapy Alone or in Combination with Massage on Dysmenorrhea: A Systematic Review and Meta-analysis
}

\section{O efeito da aromaterapia sozinha ou em combinação com massagem na dismenorreia: Uma revisão sistemática e meta-análise}

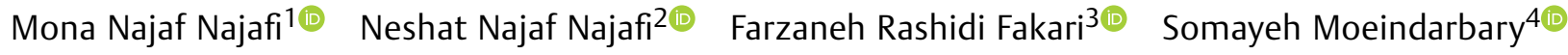 \\ Fatemeh Abdi ${ }^{\circledR}$ Zeinab Sadat Hoseini ${ }^{6 \odot}$ Masumeh Ghazanfarpour ${ }^{7 \odot}$
}

${ }^{1}$ Clinical Research Development Unit, Mashhad University of Medical Address for correspondence Masumeh Ghazanfarpour, PhD, Sciences, Imam Reza Hospital, Mashhad, Iran Kerman, Kerman Province, Iran

${ }^{2}$ Clinical Research Development Unit, Mashhad University of Medical (e-mail: Masumeh.ghazanfarpour@yahoo.com).

Sciences, Imam Reza Hospital, Mashhad, Iran

${ }^{3}$ Department of Midwifery and Reproductive Health, School of Medicine, North Khorasan University of Medical Sciences, Bojnurd, Iran

${ }^{4}$ Department of Obstetrics and Gynecology, Neonatal and Maternal

Research Center, Mashhad University of Medical Sciences, Mashhad, Iran

${ }^{5}$ School of Nursing and Midwifery, Alborz University of Medical

Sciences, Karaj, Iran

${ }^{6}$ Faculty of Medicine, Islamic Azad University of Mashhad, Mashhad,

Iran

${ }^{7}$ Student Research Committee, Kerman University of Medical

Sciences, Kerman, Iran

Rev Bras Ginecol Obstet 2021;43(12):968-979.

\begin{abstract}
Objective The aim of the present systematic review meta-analysis is to assess the effect of olfactory stimulation on reducing dysmenorrhea.

Methods Systematic search was conducted in several databases, such as PubMed, Web of Science, Cochrane, and Scopus, to identify relevant research up to October 26, 2019. The identified studies were evaluated based on a modified Jadad scale. The intervention involves aromatherapy alone or in combination with essential oils. There was no restriction for the control group such as a placebo group or other common treatments. The Comprehensive Meta-Analysis Version 2 (Bio stat, Englewood, NJ, USA) was used for meta-analysis. Cochran's $Q$ and 12 tests were utilized.

Keywords Results The findings of our meta-analysis, which contained 13 trials ( 15 data), showed

- dysmenorrhea that dysmenorrhea decreased significantly in the group receiving aromatherapy with

- herbal medicine

- aroma oil herbal compared with the control group (standardized mean difference [SMD] =-

- aromatherapy 0.795 ; $95 \%$ confidence interval [Cl]: -0.922 to- $0.667 ; 17$ trials $\mathrm{O}<0.001$ ); heterogeneity; $I 2=19.47 \% ; p=0.236)$. In addition, four studies with insufficient data were not
\end{abstract}

received

December 5, 2020

accepted

September 3, 2021
DOI https://doi.org/ $10.1055 / \mathrm{s}-0041-1740210$ ISSN $0100-7203$ (c) 2021. Federação Brasileira de Ginecologia e Obstetrícia. All rights reserved.

This is an open access article published by Thieme under the terms of the Creative Commons Attribution License, permitting unrestricted use, distribution, and reproduction so long as the original work is properly cited. (https://creativecommons.org/licenses/by/4.0/)

Thieme Revinter Publicações Ltda., Rua do Matoso 170, Rio de Janeiro, RJ, CEP 20270-135, Brazil 


\section{Resumo}

\section{Palavras-chave \\ - dismenorreia \\ - fitoterapia \\ - óleo de aroma \\ - aromaterapia}

included in our meta-analysis. The results of all studies suggested that aromatherapy with herbal medicine group compared with control group is effective.

Conclusion Aromatherapy with herbal medicine decreased dysmenorrhea. This treatment was particularly effective when aroma oil was combined with massage or when a mixture of aroma oil was used for the treatment of dysmenorrhea.

Objetivo O objetivo desta revisão sistemática-metanálise é avaliar o efeito da estimulação olfatória na redução da dismenorreia.

Métodos Pesquisa sistemática foi realizada em várias bases de dados, como PubMed, Web of Science, Cochrane e Scopus para identificar pesquisas relevantes até 26 de outubro de 2019. Os estudos identificados foram avaliados com base em uma escala de Jadad modificada. A intervenção envolve aromaterapia sozinha ou em combinação com óleos essenciais. Não houve restrição para o grupo de controle, como um grupo de placebo ou outros tratamentos comuns. O Comprehensive Meta-Analysis Version 2 (Bio stat, Englewood, NJ, EUA) foi usado para meta-análise. Os testes Q e 12 de Cochran foram utilizados.

Resultados Os resultados da nossa meta-análise, que continha 13 ensaios (15 dados), mostraram que a dismenorreia diminuiu significativamente no grupo que recebeu aromaterapia com ervas em comparação com o grupo de controle (diferença média padronizada $[\mathrm{DMP}]=-0,795$; intervalo de confiança [IC] de 95\%: -0,922 a- 0,667; 17 ensaios $O<0,001$ ); heterogeneidade; $I 2=19,47 \% ; p=0,236$ ). Além disso, quatro estudos com dados insuficientes não foram incluídos em nossa meta-análise. Os resultados de todos os estudos sugeriram que a aromaterapia com o grupo de fitoterápicos em comparação com o grupo de controle é eficaz.

Conclusão A aromaterapia com fitoterapia diminuiu a dismenorreia. Este tratamento foi particularmente eficaz quando o óleo aromático foi combinado com massagem ou quando uma mistura de óleo aromático foi usada para o tratamento da dismenorreia.

\section{Introduction}

Menstrual pain, a common complaint expressed by $\sim 25$ to $97 \%$ of women, can influence the quality of life in women. ${ }^{1,2}$ Dysmenorrhea refers to painful menstruation associated with several adverse effects, including nausea and vomiting, back pain, fatigue, and abdominal cramps. ${ }^{3}$ The severest pain is experienced in the first day of menstruation, and it takes a downward turn in the remaining days. Moreover, the pelvic pain associated with menstrual cycle is caused by the secondary dysmenorrhea coupled with pelvic discomforts, which is common during reproductive age and ovulation. Dysmenorrhea is reported to be the most prevalent cause of absenteeism in female students and employees. ${ }^{4}$

The incidence of dysmenorrhea is reported to be between 28 and $71.7 \%$, but these figures vary worldwide. ${ }^{5}$

The primary causes of dysmenorrhea are uterine contraction, vasoconstriction, inflammation, and the release of inflammatory mediators. Diminished progesterone level in the late luteal phase leads to the activation of cyclooxygenase and the biosynthesis of prostaglandin. Elevated prostaglandin production increases uterine tone and contractions, followed by dysmenorrhea. ${ }^{6}$ It has been shown that dysmenorrhea is a major disease affecting physical, social, and psychological parameters including social, emotional, and mental health. ${ }^{7}$ Dysmenorrhea may interfere with sports activities, disrupt communication with family and friends, and lower the quality of life. ${ }^{8,9}$

Drug therapy is commonly used for the management of dysmenorrhea, especially anti-inflammatory agents, and is the first line in the treatment of primary dysmenorrhea. Nevertheless, these drugs present documented unwanted complications, including drowsiness, headache and dyspepsia, ${ }^{10}$ nausea, vomiting, rashes, nervous disorders, emotional disturbances, bleeding tendency, metabolic disorders, and many more, including cancers and death. ${ }^{11}$ Another therapeutic regimen for dysmenorrhea involves the use of hormonal agents, such as oral contraceptive. ${ }^{12}$ By reducing prostaglandins, these agents have a soothing effect on dysmenorrhea. Also, hormonal therapy is recommended when treatment with non-steroidal antiinflammatory drugs is ineffective or when contraceptive methods are preferred. ${ }^{13}$ Despite the effect of these agents on pain reduction, irregular bleeding is a major factor that provokes women's dissatisfaction with hormonal treatment. ${ }^{14}$ Other side effects of this therapy include headache, nausea, mood 
changes, and weight gain. ${ }^{13}$ Medicinal plants have received growing attention for the attenuation of dysmenorrhea, particularly due to the reluctance of young women to hormonal drug administration, the complications of chemical medications, and the high cost of raw materials. ${ }^{15}$ However, most of these treatments cannot be administered by nurses, and routine drugs exhibit adverse effects or produce short-term effects. ${ }^{16}$ Despite the effectives of these drugs in alleviating premenstrual syndrome, women believe that these symptoms can be managed without using any drug or prefer using traditional and alternative techniques. ${ }^{17}$ There are various complementary and alternative medicine (CAM) methods used for menstrual pain relief, such as behavioral interventions, acupuncture, herbal medicine, transcutaneous electrical nerve stimulation (TENS), omega-3 fatty acids, vitamin pills, ${ }^{18}$ and aromatherapy. As a safe therapeutic technique, aromatherapy relies on plantbased essential oils (Buckle, 2001), ${ }^{19}$ including melissa, lavender, and eucalyptus.

Many clinical studies assessed the effect of aromatherapy on dysmenorrhea. Three studies showed a significant reduction of pain in patients receiving rose essential oil in comparison with a control group. ${ }^{3,20,21}$ Studies showed that lavender was effective both as monotherapy ${ }^{10,15,22}$ and in combination with another oil. ${ }^{23-26}$ Peppermint, ${ }^{27}$ rosemary, ${ }^{22}$ and geranium essential oils ${ }^{28}$ have shown to be effective in clinical studies. Pervious meta-analyses have illustrated the effectiveness of aromatherapy as a complementary method in reducing dysmenorrhea. ${ }^{29,30}$ According to the results of a meta-analysis, the use of essential oil in combination with massage was more effective than the control group. However, the study did not clarify whether a mixture of aroma oils or a single oil produced greater efficacy. Recently, new trials with a welldesigned methodology have been published; therefore, it is necessary to update the meta-analysis. The aim of the present systematic review and meta-analysis is to assess the effect of olfactory stimulation in the treatment of dysmenorrhea.

\section{Methods}

A comprehensive systematic search without any language restriction was conducted in several databases such as PubMed, Web of Science, Cochrane, and Scopus using the follwing keywords: (dysmenorrhea) OR (menstrual cramp) OR (menstrual pain*) OR (pain*, menstrual) OR (painful menstruation*) OR (menstruation*, painful)) AND (aromatherapy) OR (Aroma*) OR (aromatic therapy) OR (fragrance) OR (fragrant oil ${ }^{*}$ ) OR (scent) OR (massage therapy) OR (medical massage) OR (massage). The relevant studies were investigated up to October 26, 2019. All terms were searched in the title, abstract, and key words of the articles. In addition, the bibliography of the selected articles was manually searched to identify other relevant studies missed in the electronic search. Gray literature was not included in the present review.
We examined clinical trials on girls and women of childbearing age (18-45 years old) who experienced menstrual pain. The intervention had to involve aromatherapy alone or combined with essential oils in the form of inhalation or massage. There was no restriction regarding the control group; therefore, no treatment, a placebo group, or other common treatments for dysmenorrhea were considered. The severity of pain should be assessed by a valid self-reported instrument, such as a numerical rating scale (NRS) or visual analog scale (VAS).

The databases were searched by two independent researchers, and duplicate papers or papers that did not meet the inclusion criteria were excluded. The selection process is shown in - Fig. 1. Observational studies, reviews, letter to the editor and case reports were excluded. Additionally, publications written in a language other than English were also excluded. Three English abstracts (full texts were available in Farsi) were explored. $20,21,23,28,31-48$

Two authors assessed the quality of the selected studies according to the Modified Jadad Scale for Randomized Controlled Trials. This assessment tool comprises eight specific items, including a description of randomization, appropriate randomization method, blinding description, appropriate blinding method, description of withdrawals and dropouts, description of inclusion and exclusion criteria, description of adverse effects, assessment method, and the description of statistical analysis. The scores range from 0 to 8 , with higher scores indicating a higher quality. A score below 4 indicates low quality.

The data was extracted by two researchers. Any disagreements were settled through consensus and arbitration of a third person.

The selected studies were reviewed, and the following data was extracted by two authors: first author's name, year of study, place of study, type of study design, participants, the age of participants, intervention and control groups, the number of participants in the intervention and control/placebo groups, duration of study, sample dropout rate (\%), measurement method, minimal primary dysmenorrhea for inclusion in the study, and the primary outcome. The primary outcome was pain, which was measured by VAS score, numerical rating scales, or other validated instruments.

In the present study, the Comprehensive Meta-Analysis Version 2 software (Bio stat, Englewood, NJ, USA) was used for the meta-analysis. We used Cochran's $Q$ and $I^{2}$ tests to evaluate heterogeneity and homogeneity, respectively. If the test result of Cochran's $Q$ was $p<0.05$, the heterogeneity of studies was confirmed. Moreover, $\mathrm{I}^{2}$ values of $25 \%, 50 \%$, or $75 \%$ exhibited low, moderate, or high heterogeneity, respectively. If heterogeneity was confirmed, we used the random effects model for the analysis. To present treatment effects, we used a forest plot that demonstrated the effect size, and a confidence interval of $95 \%$. The Begg rank correlation and the Egger intercept tests were employed to evaluate publication bias. We examined a funnel plot for checking publication 


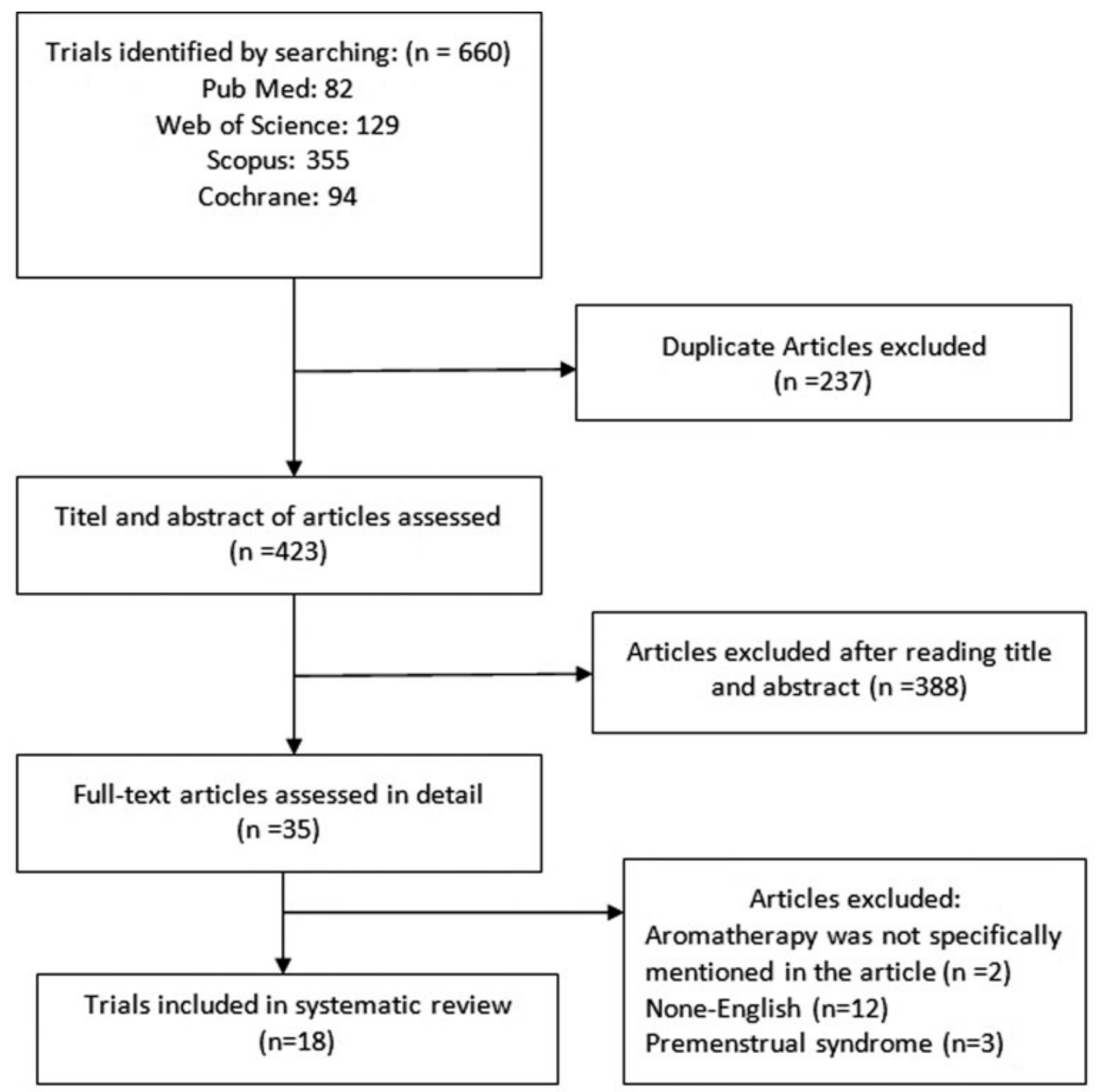

Fig. 1 Provides flowchart of study selection for the review.

bias, and the number of missing studies was computed by the Duval and Tweedie Trim and Fill program.

\section{Results}

The review of literature based on the above-mentioned search strategy yielded 660 articles, 237 of which were duplicate and, therefore, removed. Subsequently, we reviewed the titles and abstracts of studies, excluding 388 articles that had irrelevant titles or abstracts. In the end, 35 full-text articles were assessed completely, of which 17 papers were excluded. Aromatherapy was not specifically stated in two article, ${ }^{4,32} 12$ articles were not in English, ${ }^{18,33-43}$ and the symptoms of premenstrual syndrome had been examined in three papers. ${ }^{17,44,45}$ Finally,
18 clinical trials undertaken until October 26, 2019 were included in this systematic review. The flowchart identifying the included articles is shown in - Fig. 1.

These studies are listed in - Table $\mathbf{1}$. The trials consisted of a total of 1,677 patients. All of these studies targeted adult patients under 35 years of age. The essential oils consisted of lavender essence (seven studies), rose essential oil (three studies), rosemary oil (one study), ginger oil (one study), Geranium essential oil (one study), and peppermint oil (one study) as well as a combination of several essential oils (seven studies).

The selected studies were evaluated based on a modified Jadad scale. The scale includes 8 items. Most of the articles (17 papers) had high quality (a Jadad score of 5-8), and only one was of low quality (a Jadad score of 4). In 8 papers, 
972 The Effect of Aromatherapy with Massage on Dysmenorrhea Najaf Najafi et al.

Table 1 The quality assessment of the selected articles

\begin{tabular}{|c|c|c|c|c|c|c|c|c|c|c|}
\hline & Registration code & $\begin{array}{l}\text { Randomization } \\
\text { mention }\end{array}$ & $\begin{array}{l}\text { Random } \\
\text { sequence } \\
\text { generation }\end{array}$ & $\begin{array}{l}\text { Blinding of } \\
\text { participants } \\
\text { and } \\
\text { personnel }\end{array}$ & $\begin{array}{l}\text { Blinding of } \\
\text { outcome } \\
\text { assessment }\end{array}$ & $\begin{array}{l}\text { Description of } \\
\text { withdrawals } \\
\text { and dropouts }\end{array}$ & $\begin{array}{l}\text { Clear } \\
\text { description } \\
\text { of the } \\
\text { inclusion } \\
\text { and exclusion } \\
\text { criteria }\end{array}$ & $\begin{array}{l}\text { Description } \\
\text { of the method } \\
\text { used to assess } \\
\text { adverse effects }\end{array}$ & $\begin{array}{l}\text { The method } \\
\text { of statistical } \\
\text { analysis }\end{array}$ & $\begin{array}{l}\text { Total } \\
\text { score }\end{array}$ \\
\hline $\begin{array}{l}\text { Apay et al. } \\
(2012)^{22}\end{array}$ & - & 1 & 0 & 1 & 0 & 1 & 1 & 1 & 1 & 6 \\
\hline $\begin{array}{l}\text { Amiri Farahani } \\
\text { et al. }(2012)^{24}\end{array}$ & IRCT138902153869N13869 & 1 & 0 & 1 & 0 & 1 & 1 & 1 & 1 & 6 \\
\hline $\begin{array}{l}\text { Ataollahi et al. } \\
(2015)^{21}\end{array}$ & IRCT201311216807N10 & 1 & 1 & 1 & 1 & 1 & 1 & 1 & 1 & 8 \\
\hline $\begin{array}{l}\text { Azima et al. } \\
(2015)^{10}\end{array}$ & IRCT2013022611945N2 & 1 & 1 & 0 & 1 & 1 & 1 & 0 & 1 & 6 \\
\hline $\begin{array}{l}\text { Bakhtshirin } \\
\text { et al. }(2015)^{15}\end{array}$ & - & 1 & 0 & 1 & 1 & 1 & 1 & 0 & 1 & 6 \\
\hline $\begin{array}{l}\text { Beiranvand } \\
\text { et al. }(2015)^{31}\end{array}$ & IRCT201310297697N2 & 1 & 1 & 1 & 1 & 1 & 1 & 0 & 1 & 7 \\
\hline $\begin{array}{l}\text { Davari et al. } \\
(2014)^{23}\end{array}$ & - & 1 & 0 & 1 & 1 & 1 & 1 & 1 & 1 & 7 \\
\hline $\begin{array}{l}\text { Raisi Dehkordi } \\
\text { et al. }(2014)^{47}\end{array}$ & IRCT201105086412N1 & 1 & 1 & 1 & 1 & 1 & 1 & 1 & 1 & 8 \\
\hline $\begin{array}{l}\text { Kim et al. } \\
(2011)^{18}\end{array}$ & - & 0 & 0 & 0 & 0 & 1 & 1 & 1 & 1 & 4 \\
\hline $\begin{array}{l}\text { Marzouk et al. } \\
(2013)^{25}\end{array}$ & - & 1 & 1 & 1 & 1 & 1 & 1 & 1 & 1 & 8 \\
\hline Ou et al. $(2012)^{26}$ & - & 1 & 1 & 1 & 1 & 1 & 1 & 0 & 1 & 7 \\
\hline $\begin{array}{l}\text { Uysal et al. } \\
(2016)^{3}\end{array}$ & - & 1 & 1 & 0 & 0 & 1 & 1 & 0 & 1 & 5 \\
\hline Hur et al. $(2012)^{1}$ & - & 0 & 0 & 0 & 0 & 1 & 1 & 1 & 1 & 4 \\
\hline $\begin{array}{l}\text { Nikjou et al. } \\
(2016)^{48}\end{array}$ & IRCT201470616252N2 & 1 & 1 & 1 & 1 & 1 & 1 & 1 & 1 & 8 \\
\hline $\operatorname{Rizk}(2013)^{27}$ & - & 1 & 0 & 1 & 0 & 1 & 1 & 0 & 1 & 5 \\
\hline $\begin{array}{l}\text { Sadeghi Aval Shahr } \\
\text { et al. }(2015)^{20}\end{array}$ & - & 1 & 0 & 1 & 0 & 1 & 1 & 1 & 1 & 6 \\
\hline $\begin{array}{l}\text { Sajjadi et al. } \\
(2018)^{28}\end{array}$ & IRCT2017013132329N1 & 1 & 0 & 1 & 1 & 1 & 1 & 0 & 1 & 6 \\
\hline $\begin{array}{l}\text { Han et al. } \\
(2006)^{16}\end{array}$ & - & 1 & 0 & 1 & 0 & 1 & 1 & 1 & 1 & 6 \\
\hline
\end{tabular}

suitable randomization methods were described, and patients were blind to the randomization in 14 studies. The rate of withdrawals and dropouts had been reported in all studies, whereas the assessment of adverse effects was only discussed in 11 articles. The statistical methods and inclusion criteria were adequately described in all RCTs. The quality assessment of the selected articles is depicted in -Table 1. A comprehensive list of the selected studies' characteristics is outlined in -Table 2.

The standardized mean difference (SMD) of dysmenorrhea change was -0.904 (95\% confidence interval $\mathrm{CI}$ : -1.023 to- $0.786 ; 16$ trials, $p<0.001$ ) ( - Fig. 2 ). However, the heterogeneity of the included studies was moderate $\left(\mathrm{I}^{2}=60.43 \%\right)$ and significant $(p=0.003)$. To detect the potential source of this heterogeneity, sensitivity analyses were performed, with the results indicating that heterogeneity was mainly caused by inclusion of Nikjou et al.'s ${ }^{48}$ study. The removal of this study caused a slight decrease in (SMD $=-0.795 ; 95 \% \mathrm{CI}:-0.922$ to- $0.667 ; 15$ trials), but the heterogeneity reached acceptable level $\left(p=0.236 ; \mathrm{I}^{2}=19 \%\right)$ (-Fig.3). The results of our meta-analysis of 15 trials showed that dysmenorrhea dropped significantly in the group of aromatherapy with herbal medicine compared with the placebo. The subgroup involved the type of treatment (a combination of aroma oils versus a single type of oil, and both aroma and massage versus aroma alone). The results of the analysis of the lavender subgroup indicate higher effectiveness in the intervention than in the control group $(p<0.001)$ ( - Table 3 ). The results of subgroup analysis revealed that patients receiving a combination of massage + aromatherapy reported greater pain relief than those receiving aromatherapy alone $(p<0.001)$. The two groups were not significantly different in the subgroup analysis comparing a mixture of aroma oils and a single oil $(p=0.34)$.

Four studies with insufficient data were not included in our meta-analysis. The results of three studies ${ }^{1,16,27}$ are presented as medians and interquartile ranges, and one study as graded severity of dysmenorrhea (mild, moderate, 
The Effect of Aromatherapy with Massage on Dysmenorrhea Najaf Najafi et al. 973

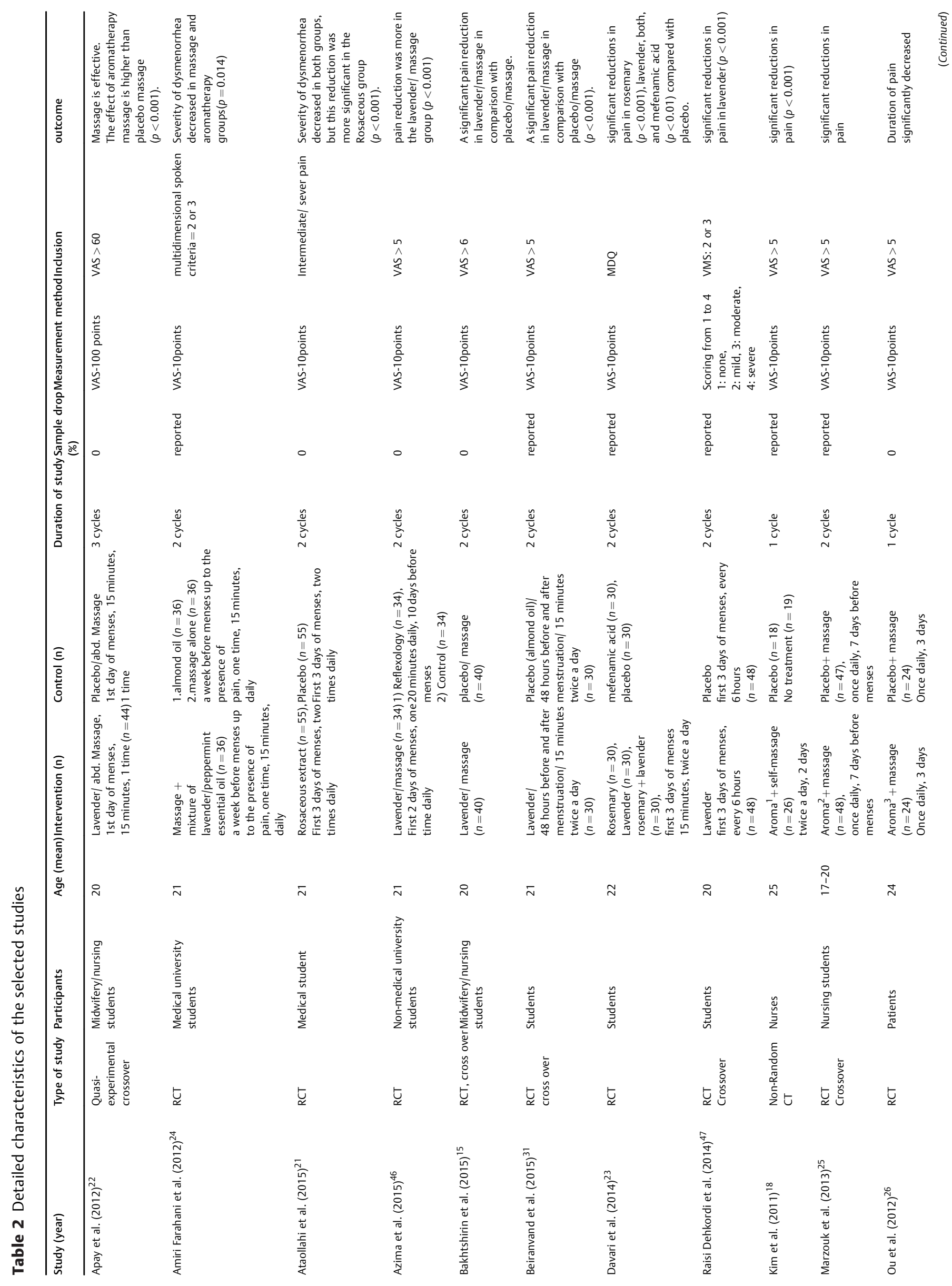




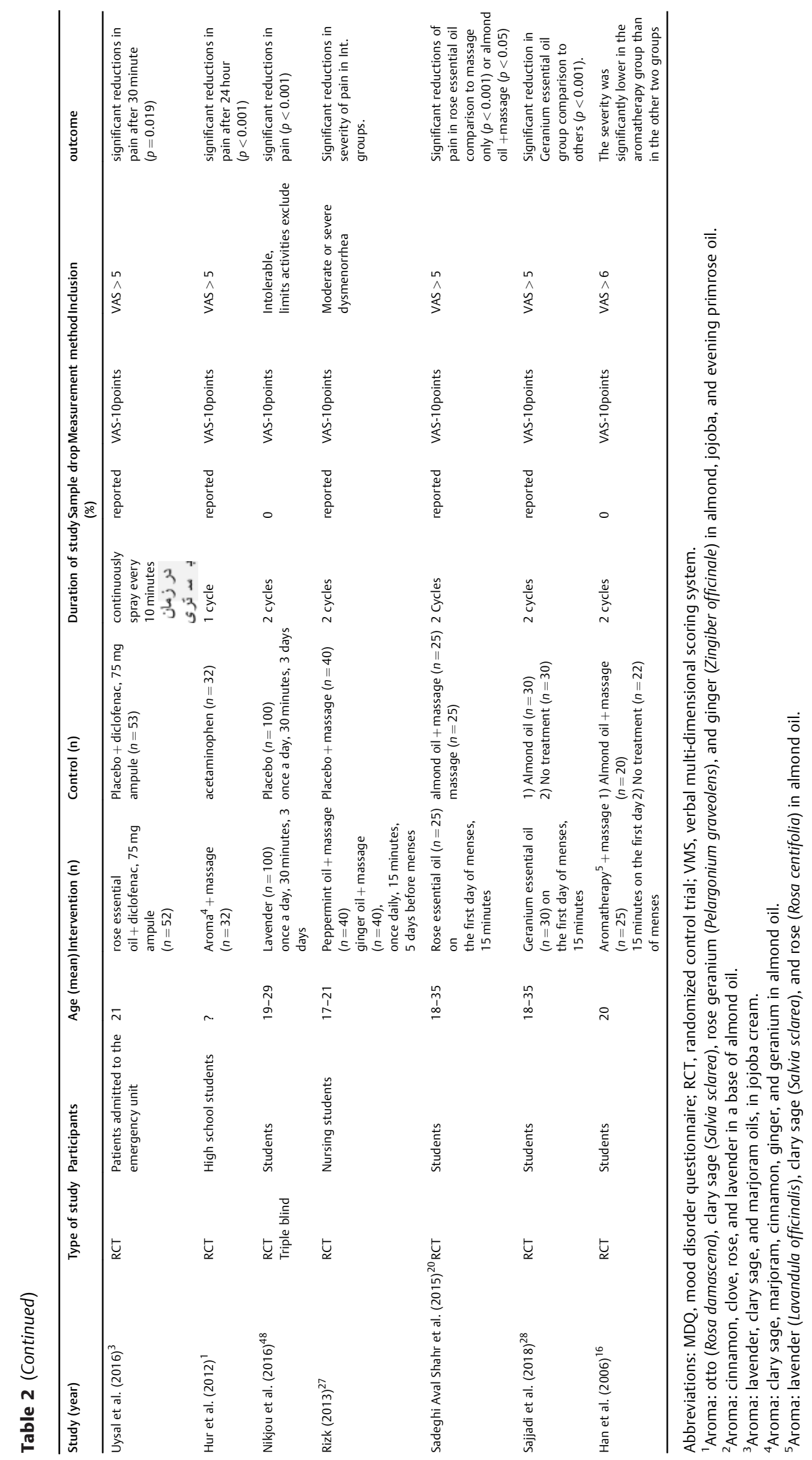




\begin{tabular}{|c|c|c|c|c|c|c|c|c|c|c|c|}
\hline \multirow[t]{2}{*}{ Study name } & \multicolumn{7}{|c|}{ Statistics for each study } & \multicolumn{4}{|c|}{ Stddeff in means and $95 \% \mathrm{Cl}$} \\
\hline & $\begin{array}{l}\text { Std diff } \\
\text { in mears }\end{array}$ & $\begin{array}{l}\text { Standard } \\
\text { error }\end{array}$ & Variance & $\begin{array}{l}\text { Lower } 1 \\
\text { limit }\end{array}$ & $\begin{array}{l}\text { Upper } \\
\text { limit }\end{array}$ & Z-Value & -Value & & & & \\
\hline Sadeghi Rose OII & -0.648 & 0.290 & 0.084 & -1.217 & -0.080 & -2.235 & 0.025 & & & & | \\
\hline Nikjou Lavender & -1.586 & 0.162 & 0.026 & -1.904 & -1.268 & -9.782 & 0.000 & & & & \\
\hline Sajadi Geranium & -0.540 & 0.211 & 0.044 & -0.953 & -0.126 & -2.560 & 0.010 & & & & \\
\hline Ataollahi Rosaceous & -0.697 & 0.196 & 0.039 & -1.081 & -0.312 & -3.547 & 0.000 & & & & \\
\hline Davari Lavender & -0.913 & 0.276 & 0.076 & -1.454 & -0.371 & -3.306 & 0.001 & & & & \\
\hline Davari Rosmary & -0.904 & 0.273 & 0.075 & -1.439 & -0.368 & -3.306 & 0.001 & & & & \\
\hline Davari Rosmary +lavender & -0.904 & 0.273 & 0.075 & -1.439 & -0.368 & -3.305 & 0.001 & & & & \\
\hline Amiri Farahani Peppermint+lavender & -0.707 & 0.266 & 0.071 & -1.229 & -0.186 & -2.657 & 0.008 & & & & \\
\hline Azima Lavender & -0.851 & 0.253 & 0.064 & -1.347 & -0.354 & -3.358 & 0.001 & & & & \\
\hline Beranvand Lavender & -0.895 & 0.271 & 0.073 & -1.426 & -0.364 & -3.305 & 0.001 & & & & \\
\hline Bakhtshirin tavender & -1.411 & 0.250 & 0.062 & -1.901 & -0.922 & -5.648 & 0.000 & & & & \\
\hline Apy lavender & -1.202 & 0.328 & 0.107 & -1.845 & -0.560 & -3.670 & 0.000 & & & & \\
\hline Kim Avomather apy oils & -1.483 & 0.366 & 0.134 & -2.201 & $-0.7 \notin 5$ & -4.048 & 0.000 & & & & \\
\hline Marzouk aromatherapy oil & -0.540 & 0.209 & 0.044 & -0.949 & -0.130 & -2.583 & 0.010 & & & & \\
\hline Uysal Rose oil & -0.545 & 0.199 & 0.040 & -0.936 & $5-0.166$ & -2.742 & 0.006 & & & & \\
\hline \multirow[t]{3}{*}{ Ou aromatherapy oil } & -0.610 & 0.295 & 0.087 & -1.189 & -0.031 & -2.066 & 0.039 & & & & \\
\hline & -0.904 & 0.060 & 0.004 & -1.023 & -0.786 & -14.972 & 0.000 & & & & \\
\hline & & & & & & & & -8.00 & -4.00 & 4.00 & 8.00 \\
\hline
\end{tabular}

Fig. 2 Aromatherapy effect on the severity of dysmenorrhea based on the random effects model.

and severe $).{ }^{47}$ Han et al. ${ }^{16}$ drew a comparison between the effect of almond oil + massage and placebo with no treatment $(n=22)$. Regression aromatherapy was associated with significant changes in the severity of dysmenorrhea (first day: $\beta=0.31, p=0.02$; second day: $\beta=0.33, p=0.006$ ) compared with the control and placebo groups. ${ }^{16}$ Hur et al. ${ }^{1}$ compared the effect of aroma (including clary sage, marjoram, cinnamon, ginger, and geranium in almond oil)
+ massage $(n=32)$ to that of a control group using acetaminophen $(n=32)$. Regression aromatherapy was strongly associated with a decrease in the severity of dysmenorrhea $(\beta=$ $-3.07,95 \% \mathrm{CI}-3.83$ to $-2.29, t=-8.00, P<0.001)$. In a 2013 study by Rizk, ${ }^{27}$ the effects of both peppermint oil + massage $(n=40)$ and ginger oil + massage $(n=40)$ were compared with placebo, with the findings suggesting a significant reduction in the severity of pain. According to Raisi Dehkordi

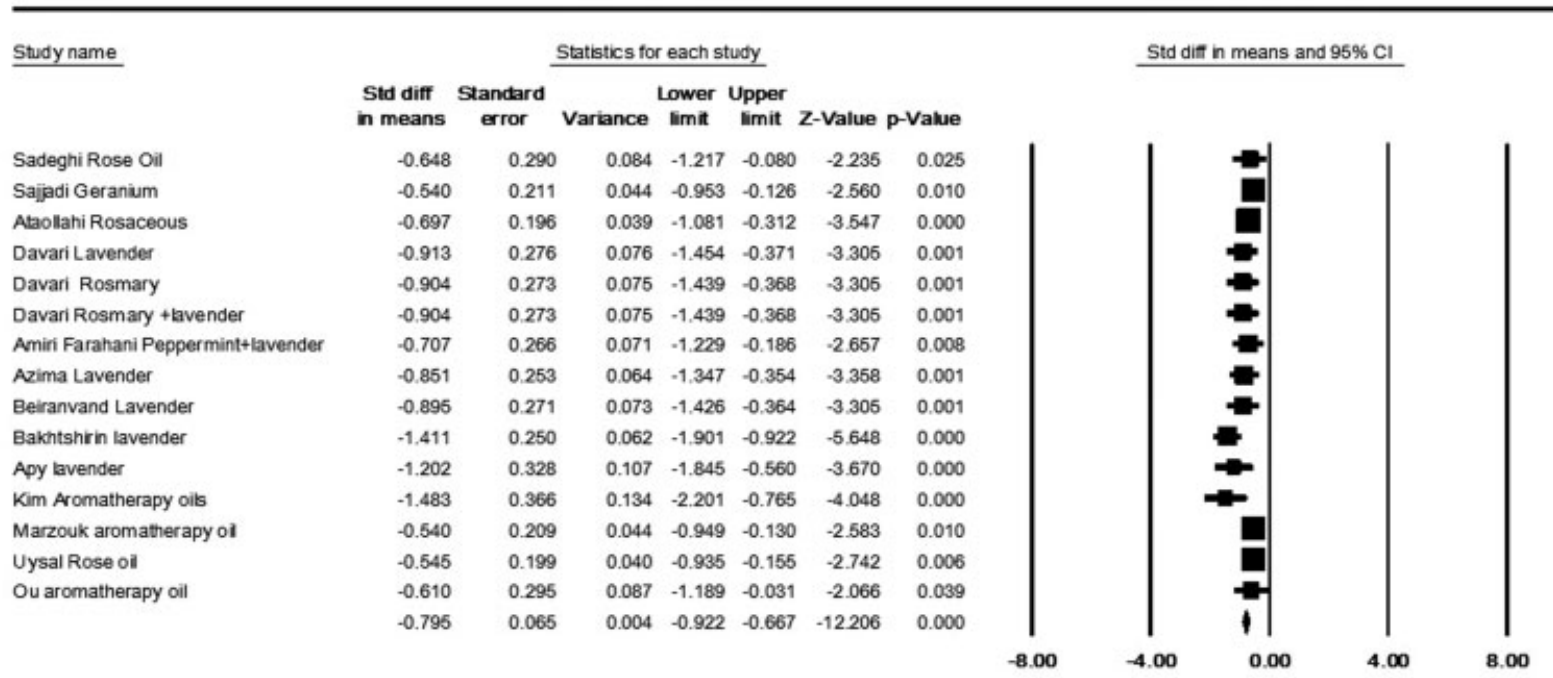

\section{Aroma Control}

Fig. 3 Aromatherapy effect on the severity of dysmenorrhea based on the random effects model after removal of one study which caused heterogeneity. 
Table 3 Subgroup analyses of the effect of aromatherapy in dysmenorrhea

\begin{tabular}{|c|c|c|c|c|c|c|}
\hline \multirow[t]{2}{*}{ Variable } & \multirow[t]{2}{*}{ Number of RCTs } & \multirow[t]{2}{*}{$\begin{array}{l}\text { Sample size } \\
\text { (treatment/control) }\end{array}$} & \multicolumn{2}{|c|}{$\begin{array}{l}\text { Test of } \\
\text { heterogeneity }\end{array}$} & \multirow[t]{2}{*}{$P$-value } & \multirow{2}{*}{$\begin{array}{l}\text { Fixed }=\text { effect model } \\
\text { SMD }(95 \% \mathrm{CI})\end{array}$} \\
\hline & & & $P$ & $\mathrm{I}^{2}(\%)$ & & \\
\hline \multicolumn{7}{|l|}{ Types of treatment } \\
\hline Massage + aromatherapy & 9 & 540 & 0.7 & $0 \%$ & $<0.001$ & $-0.915(-1.09$ to -0.73$)$ \\
\hline Aromatherapy alone & 9 & 729 & 0.13 & $34 \%$ & $<0.001$ & $-0.741(-0.89$ to -0.58$)$ \\
\hline Test for subgroup difference & & & & & & $p<0.001$ \\
\hline \multicolumn{7}{|l|}{ Types of treatment } \\
\hline A mixture of aroma oils & 7 & 452 & 0.410 & $3 \%$ & $<0.001$ & $-0.865(-1.01$ to -0.715$)$ \\
\hline Single oil & 11 & 817 & 0.273 & $20 \%$ & $<0.001$ & $-0.75(-0.97$ to -0.53$)$ \\
\hline Test for subgroup difference & & & & & & $p=0.34$ \\
\hline
\end{tabular}

Abbreviations: $\mathrm{Cl}$, confidence interval; SMD, standardized mean difference.

et al., ${ }^{47}$ the ordinal logistic regression indicated that aromatherapy was significantly effective in relieving dysmenorrhea symptoms $(p<0.001)$.

\section{Discussion}

In this questionable pain relief mechanism, aromatherapy has been proven to influence the olfactory-hippocampal pathway, which stimulates the putative and gamma-aminobutyric acid (GABA)ergic neurons (such as cholinergic neurons), regulates the release of acetylcholine, or changes the feeling of pain. The olfactory receptors can be triggered by essential oil inhalation, which transmits signals to the brain and induces a composition of memory, thought, and emotion. Subsequently, it leads to the secretion of some internal chemicals such as endorphin and enkephalin, which can alleviate anxiety and pain, respectively. ${ }^{3}$

The identified major compounds of rose oil are $\beta$-citronellol (14.5-47.5\%), nonadecane (10.5-40.5\%), geraniol (5.5$18 \%)$, and nerol and kaempferol. Rose oil has many therapeutic applications, including anticonvulsant, and analgesic and hypnotic effects. ${ }^{49}$ Three studies assessed the effect of rose oil on dysmenorrhea. In the study of Ataollahi et al., ${ }^{21}$ the severity of dysmenorrhea in medical students fell significantly in the rosaceous group compared with the placebo group. In the research, by Uysal et al., ${ }^{3}$ rose essential oil + diclofenac was more effective in pain relief after 30 minutes compared with placebo + diclofenac. Sadeghi Aval Shahr et al. ${ }^{20}$ reported a significant pain relief in the rose essential oil group compared with the massage only and the almond oil + massage groups. The essential oil of the geranium plant contains geraniol, citronellol, terpineol, and alcohols, which have anticancer, antimicrobial, antiinflammatory, analgesic, and antioxidant effects. ${ }^{50}$ Sajjadi et al ${ }^{28}$ found a significant pain relief in patients receiving geranium essential oil in comparison with almond oil. The mechanism of pain relief in dysmenorrhea may be related to the analgesic effect of geranium.
$\operatorname{Rizk}^{27}$ compared the effect of peppermint oil + massage with that of placebo, with their results suggesting a significant reduction in the severity of pain in the peppermint oil + massage group.

Peppermint oil has antispasmodic, ${ }^{51-53}$ analgesic, ${ }^{54}$ antiinflammatory, and antimicrobial effect, ${ }^{55}$ and it can inhibit prostaglandin $\mathrm{F} 2 \alpha^{56,57}$

The bioactive compounds of Rosmarinus officinalis oil significantly decreased the expression of IL- $1 \beta$ and TNF- $\alpha$ and inhibited COX-2 expression. ${ }^{58}$ Davari et al. $(2014)^{23}$ reported a significant pain relief in the rosemary group compared with the placebo group.

Some aromatherapy textbooks suggest that two or more oils should be combined to achieve a synergic effect. ${ }^{18,22}$ Consistent with this hypothesis, our meta-analysis revealed that a mixture of aroma oil was more effective than a single aroma oil.

Our meta-analysis shows that a combined use of both aromatherapy and massage is more effectiveness than aromatherapy alone. There is no detailed information on how to relieve pain by massage. The gate control theory of pain is one of the most influential theories which is according to in fact so that dorsal spinal horn cells acts like a gate which inhibits or facilitates transmission from the body to the brain on according to the diameters of the active peripheral fibers. There are three types of nerve fibers, A, B and C, based on the conduction velocity and the axonal diameter. The massage signals are rapidly transmitted via the sheathed A fiber, whereas pain signals are slowly transmitted via the unsheathed $C$ fibers. The massage transfers these signals rapidly, developing pressure signals that subsequently close the pain signal gate.

According to the gate control theory, such signals encounter "nerve gates" on the spinal cord and should be cleared via these gates to travel to the brain. Other benefits of massage include the relaxation of contracted muscles, reduction of stress, and enhancement of lymph and blood circulation. ${ }^{10}$ The effect of lavender on diminishing pain can be attributed to its sedative, antidepressant, antispasmodic, antiflatulent 
impact. It can also be used to treat infertility, infection, anxiety, fever, and stress. ${ }^{48}$

Our meta-analysis, in keeping with pervious meta-analyses, illustrated that aromatherapy oil in combination with massage displayed a greater effectiveness compared with the control group. ${ }^{30}$ According to the results of Sut and Kahyaoglu-Sut's ${ }^{29}$ meta-analysis, RCTs decreased the risk of bias significantly in comparison with the placebo group.

The present meta-analysis has several limitations that need to be addressed. First, the power of our meta-analysis declined in various subgroups. Secondly, plants may have different therapeutic powers depending on the country or region in which the plants are harvested. ${ }^{25}$ The absorption and metabolism of some herbs vary in different individuals. The effectiveness of herbal medicine in the treatment of dysmenorrhea may depend on the pathological source of dysmenorrhea. ${ }^{48}$ Third, different massage methods and techniques, and factors such as massage site and pain severity may have influenced our meta-analysis. The severity of dysmenorrhea reported in each study before treatment was different. For example, Ataollahi et al. ${ }^{21}$ and Apay et al. ${ }^{22}$ reported a mean severity of 4.98 and 82 . This may be due to several reasons. The highest level of menstrual pain appeared on the first day of menstruation and then subsided. ${ }^{18}$ It has also been suggested that the perception and tolerance of pain may be influenced by various factors such as culture, society, and lifestyle. ${ }^{15}$ Lastly, in some studies, the subjects were students residing in a dormitory. It may be difficult to provide suitable conditions for the application of aromatherapy in a dormitory.

\section{Conclusion}

Aromatherapy with herbal medicine was found to alleviate dysmenorrhea. Also, a combination of oil and massage had a greater effect compared with the control group. Aromatherapy is recommended to women suffering from dysmenorrhea, especially to women who are reluctant to use hormonal drugs or concerned about the complications or high costs of chemical medications and, therefore, prefer herbal medicine. However, due to heterogeneity of studies, weak methodologies, and short-term follow-ups, the findings should be interpreted with caution.

\section{Conflict of Interests}

The authors have no conflict of interests to declare.

\section{References}

1 Hur MH, Lee MS, Seong KY, Lee MK. Aromatherapy massage on the abdomen for alleviating menstrual pain in high school girls: a preliminary controlled clinical study. Evid Based Complement Alternat Med. 2012;2012:187163. Doi: 10.1155/2012/187163

2 Habibi N, Huang MS, Gan WY, Zulida R, Safavi SM. Prevalence of primary dysmenorrhea and factors associated with its intensity among undergraduate students: a cross-sectional study. Pain Manag Nurs. 2015;16(06):855-861. Doi: 10.1016/j.pmn. 2015.07.001
3 Uysal M, Doğru HY, Sapmaz E, Tas U, Çakmak B, Ozsoy AZ, et al. Investigating the effect of rose essential oil in patients with primary dysmenorrhea. Complement Ther Clin Pract. 2016; 24:45-49. Doi: 10.1016/j.ctcp.2016.05.002

4 Salmalian H, Saghebi R, Moghadamnia AA, Bijani A, Faramarzi M, Amiri FN, et al. Comparative effect of thymus vulgaris and ibuprofen on primary dysmenorrhea: A triple-blind clinical study. Caspian J Intern Med. 2014;5(02):82-88

5 Unsal A, Ayranci U, Tozun M, Arslan G, Calik E. Prevalence of dysmenorrhea and its effect on quality of life among a group of female university students. Ups J Med Sci. 2010;115(02): 138-145. Doi: 10.3109/03009730903457218

6 De Sanctis V, Soliman A, Bernasconi S, Bianchin L, Bona G, Bozzola $\mathrm{M}$, et al. Primary dysmenorrhea in adolescents: prevalence, impact and recent knowledge. Pediatr Endocrinol Rev. 2015;13 (02):512-520

7 Shewte MK, Sirpurkar MS. Dysmenorrhoea and quality of life among medical and nursing students: a cross-sectional study. Natl J Community Med. 2016;7(06):474-479

8 Al-Jefout M, Seham AF, Jameel H, Randa AQ, Ola AM, Oday AM, et al. Dysmenorrhea: prevalence and impact on quality of life among young adult Jordanian females. J Pediatr Adolesc Gynecol. 2015;28(03):173-185. Doi: 10.1016/j.jpag.2014.07.005

9 Emem EA, Hassan HE. Correlation between quality of life and dysmenorrhea among nursing schools students. Int J Nurs Sci. 2017;7(06):123-132

10 Azima S, Bakhshayesh HR, Mousavi S, Ashrafizaveh A. Comparison of the effects of reflexology and massage therapy on primary dysmenorrheal. Biomed Res (Aligarh). 2015;26(03): 471-476

11 Hakim A, Ghufran A, Nasreen J. Evaluation of anti-inflammatory activity of the pods of Iklil-ul-Malik (Astragalus hamosus Linn.). Indian J Nat Prod Resour. 2010;1(01):34-37

12 Zahradnik HP, Hanjalic-Beck A, Groth K. Nonsteroidal anti-inflammatory drugs and hormonal contraceptives for pain relief from dysmenorrhea: a review. Contraception. 2010;81(03):185-196. Doi: 10.1016/j.contraception.2009.09.014

13 Singh N, Rai S. Primary dysmenorrhoea. Indian Obstet Gynaecol. 2017;7(02):38-45

14 Zigler RE, McNicholas C. Unscheduled vaginal bleeding with progestin-only contraceptive use. Am J Obstet Gynecol. 2017; 216(05):443-450. Doi: 10.1016/j.ajog.2016.12.008

15 Bakhtshirin F, Abedi S, YusefiZoj P, Razmjooee D. The effect of aromatherapy massage with lavender oil on severity of primary dysmenorrhea in Arsanjan students. Iran J Nurs Midwifery Res. 2015;20(01):156-160

16 Han SH, Hur MH, Buckle J, Choi J, Lee MS. Effect of aromatherapy on symptoms of dysmenorrhea in college students: A randomized placebo-controlled clinical trial. J Altern Complement Med. 2006; 12(06):535-541. Doi: 10.1089/acm.2006.12.535

17 Uzunçakmak T, Ayaz Alkaya S. Effect of aromatherapy on coping with premenstrual syndrome: A randomized controlled trial. Complement Ther Med. 2018;36:63-67. Doi: 10.1016/j. ctim.2017.11.022

18 Kim YJ, Lee MS, Yang YS, Hur MH. Self-aromatherapy massage of the abdomen for the reduction of menstrual pain and anxiety during menstruation in nurses: a placebo-controlled clinical trial. Eur J Integr Med. 2011;3(03):e165-e168. Doi: 10.1016/j. eujim.2011.08.007

19 Buckle J. The role of aromatherapy in nursing care. Nurs Clin North Am. 2001;36(01):57-72

20 Sadeghi Aval Shahr H, Saadat M, Kheirkhah M, Saadat E. The effect of self-aromatherapy massage of the abdomen on the primary dysmenorrhoea. J Obstet Gynaecol. 2015;35(04):382-385. Doi: 10.3109/01443615.2014.958449

21 Ataollahi M, Akbari SA, Mojab F, Roshanaie G. Effects of aromatherapy by Rosaceous on the severity and systemic symptoms of 
primary dysmenorrhea. Adv Nurs Midwifery.. 2015;25(89): 59-67

22 Apay SE, Arslan S, Akpinar RB, Celebioglu A. Effect of aromatherapy massage on dysmenorrhea in Turkish students. Pain Manag Nurs. 2012;13(04):236-240. Doi: 10.1016/j.pmn.2010. 04.002

23 Davari M, Reihani M, Khoshrang N. The aromatherapy effect of rosemary and lavander on primary dysmenorrhea: a clinical controlled trial. Majallah-i Danishkadah-i Pizishki-i Isfahan. 2014;32(290):929-937

24 Amiri Farahani L, Heidari T, Roozbahani N, Attarha M, Akbari TorkestaniN, Bekhradi R, et al. Effect of aromatherapy on pain severity in primary dysmenorrhea. J Arak Univ Med Sci. 2012;15 (04):1-9

25 Marzouk TM, El-Nemer AM, Baraka HN. The effect of aromatherapy abdominal massage on alleviating menstrual pain in nursing students: a prospective randomized cross-over study. Evid Based Complement Alternat Med. 2013;2013:742421. Doi: $10.1155 / 2013 / 742421$

26 Ou MC, Hsu TF, Lai AC, Lin YT, Lin CC. Pain relief assessment by aromatic essential oil massage on outpatients with primary dysmenorrhea: a randomized, double-blind clinical trial. J Obstet Gynaecol Res. 2012;38(05):817-822. Doi: 10.1111/j.14470756.2011.01802.x

27 Rizk SA. Effect of aromatherapy abdominal massage using peppermint versus ginger oils on primary dysmenorrhea among adolescent girls. J Am Sci. 2013;9(11):497-505

28 Sajjadi M, Bahri N, Abavisani M. Aromatherapy massage with geranium essence for pain reduction of primary dysmenorrhea: a double blind clinical trial. Majallah-i Zanan, Mamai va Nazai-i Iran. 2018;20(12):50-57. Doi: 10.22038/ijogi.2017.10430

29 Sut N, Kahyaoglu-Sut H. Effect of aromatherapy massage on pain in primary dysmenorrhea: A meta-analysis. Complement Ther Clin Pract. 2017;27:5-10. Doi: 10.1016/j.ctcp.2017.01.001

30 Song JA, Lee MK, Min E, Kim ME, Fike G, Hur MH. Effects of aromatherapy on dysmenorrhea: A systematic review and metaanalysis. Int J Nurs Stud. 2018;84:1-11. Doi: 10.1016/j.ijnurstu.2018.01.016

31 Beiranvand S, Hosseinabadi R, Anbari K, Pirdadeh Beiranvand S, Asti P. The effect of lavender aromatherapy massage on severity and symptoms of primary dysmenorrheal. Complement Med J Fac Nurs Midwifery. 2015;5(01):1028-1041

32 Khorshidi N, Ostad SN, Mosaddegh M, Soodi M. Clinical effects of fennel essential oil on primary dysmenorrhea. Iran J Pharm Res. 2010;2(02):89-93

33 Chen Y, Shang GD, Fu GB. [Effect of massage on hemodynamics parameters of uterine artery and serum prostaglandin in treating patients with primary dysmenorrhea]. Zhongguo Zhong Xi Yi Jie He Za Zhi. 2011;31(10):1355-1358

34 Cheon JA, Lim MH. Effect of aromatherapy using nutmeg, fennel and marjoram on menstruation cramps and dysmenorrhea. J Korean Soc Cosmetol. 2013;19(06):1138-1147

35 Choi EH. Comparison of effects lavender abdominal massage and inhalation on dysmenorrhea, pain, anxiety and depression. J Korean Acad Fundam Nurs. 2009;16(03):300-306

36 Han SH, Ro YJ, Hur MH. Effects of aromatherapy on menstrual cramps and dysmenorrhea in college student woman: a blind randomized clinical trial. J Korean Acad Adult Nurs. 2001;13(03): $420-430$

37 Hyun J, Hur M. [Effect of aromatherapy on the menstrual pain in cadet women]. J Mil. Nurs Res. 2004;22(01):64-87Korean.

38 Iravani M. Clinical effects of Zataria multiflora essential oil on primary dysmenorrhea. Faslnamah-i Giyahan-i Daruyi. 2009;8 (30):54-60

39 Kim HK, Kim HG, Cheong YS, Park EW, Yoo SM. [The effect of aromatherapy on dysmenorrhea from high school girls]. J Korean Acad. Fam Med. 2001;22(06):922-929Korean.
40 Kim NY, Kim CS, Kim YS. Effect that aromatherapy gets in woman's period pains. J Korean Soc Cosmetology. 2008;14(02): 378-383

41 Lee HJ, Lee YS, Shin HY, et al. [Comparative analysis on the effects of abdominal massage using aroma oil and ordinary oil on nurses' dysmenorrhea and painful menstruation]. J Korean. Clin Nurs Res. 2006;11(02):121-133Korean.

42 Lee YM. Effects of aroma-foot-reflexology on premenstrual syndrome, dysmenorrhea and lower abdominal skin temperature of nursing students. Korean J Adult Nurs. 2011;23(05): 472-481

43 Seo JY, Kim MY. The effects of aromatherapy on dysmenorrhea, menstrual pain, anxiety, and depression in nursing students. Korean J Adult Nurs. 2008;20(05):756-764

44 Heydari N, Abootalebi M, Jamalimoghadam N, Kasraeian M, Emamghoreishi M, Akbarzadeh M. Investigation of the effect of aromatherapy with Citrus aurantium blossom essential oil on premenstrual syndrome in university students: A clinical trial study. Complement Ther Clin Pract. 2018;32:1-5. Doi: 10.1016/j. ctcp.2018.04.006

45 Matsumoto T, Asakura H, Hayashi T. Does lavender aromatherapy alleviate premenstrual emotional symptoms?: a randomized crossover trial Biopsychosoc Med. 2013;7(01):12. Doi: 10.1186/1751-0759-7-12

46 Azima S, Bakhshayesh HR, Kaviani M, Abbasnia K, Sayadi M. Comparison of the effect of massage therapy and isometric exercises on primary dysmenorrhea: a randomized controlled clinical trial. J Pediatr Adolesc Gynecol. 2015;28(06):486-491. Doi: $10.1016 /$ j.jpag.2015.02.003

47 Raisi Dehkordi Z, Hosseini Baharanchi FS, Bekhradi R. Effect of lavender inhalation on the symptoms of primary dysmenorrhea and the amount of menstrual bleeding: A randomized clinical trial. Complement Ther Med. 2014;22(02):212-219. Doi: 10.1016/j.ctim.2013.12.011

48 Nikjou R, Kazemzadeh R, Rostamnegad M, Moshfegi S, Karimollahi M, Salehi H. The effect of lavender aromatherapy on the pain severity of primary dysmenorrhea: a triple-blind randomized clinical trial. Ann Med Health Sci Res. 2016;6(04):211-215. Doi: 10.4103/amhsr.amhsr_527_14

49 Boskabady MH, Shafei MN, Saberi Z, Amini S. Pharmacological effects of rosa damascena. Iran J Basic Med Sci. 2011;14(04): 295-307

50 Gazerani A, Sarchahi Z, Hosseini SS, Abavisani M. The effect of inhalation aromatherapy of geranium on pain and physiological indices after appendectomy: a double-blind randomized clinical trial. Int J Surg Open. 2021;28:44-49. Doi: 10.1016/j. ijso.2020.12.004

51 Zielińska A. Pain in irritable bowel syndrome. In: Fichna J, editors. A comprehensive overview of irritable bowel syndrome: clinical and basic science aspects. Amsterdam: Elsevier; 2020: 145-66

52 Skalicka-Woźniak K, Walasek M. Preparative separation of menthol and pulegone from peppermint oil (Mentha piperita L.) by high-performance counter-current chromatography. Phytochem Lett. 2014;10:xciv-xcviii. Doi: 10.1016/j.phytol.2014.06.007

53 Shavakhi A, Ardestani SK, Taki M, Goli M, Keshteli AH. Premedication with peppermint oil capsules in colonoscopy: a double blind placebo-controlled randomized trial study. Acta Gastroenterol Belg. 2012;75(03):349-353

54 Özmen T, Doğan H, Güneş Gencer GY. Effect of classic massage with peppermint oil on muscle soreness and muscle strength during recovery from exercise. J Sports Perform Res. 2020;11(02): 103-111. Doi: $10.17155 /$ omuspd.606247

55 Pannuti CM, Mattos JP, Ranoya PN, Jesus AM, Lotufo RF, Romito GA Clinical effect of a herbal dentifrice on the control of plaque and gingivitis: a double-blind study. Pesqui Odontol Bras. 2003;17 (04):314-318. Doi: 10.1590/s1517-74912003000400004 
56 Ibaadillah AA, Samtyaningsih D. Effect of peppermint tea on dismenorrhoe in midwifery students of diii study program stikes Maharani Malang. J Nurs Care Biomol. 2017;2(01):6-9. Doi: $10.32700 /$ jnc.v2i1.23

57 Masoumi SZ, Asl HR, Poorolajal J, Panah MH, Oliaei SR. Evaluation of mint efficacy regarding dysmenorrhea in comparison with mefenamic acid: A double blinded randomized crossover study.
Iran J Nurs Midwifery Res. 2016;21(04):363-367. Doi: 10.4103/1735-9066.185574

58 Mengoni ES, Vichera G, Rigano LA, Rodriguez-Puebla ML, Galliano SR, Cafferata EE, et al. Suppression of COX-2, IL-1 $\beta$ and TNF- $\alpha$ expression and leukocyte infiltration in inflamed skin by bioactive compounds from Rosmarinus officinalis L. Fitoterapia. 2011; 82(03):414-421. Doi: 10.1016/j.fitote.2010.11.023 